\title{
Seeing the Urban from the Agrarian: Emerging Forms of Agrarian Urbanization in India
}

\section{Ankita Rathi}

\section{(2) OpenEdition}

\section{Journals}

\section{Electronic version}

URL: https://journals.openedition.org/samaj/7306

DOI: $10.4000 /$ samaj.7306

ISSN: 1960-6060

\section{Publisher}

Association pour la recherche sur l'Asie du Sud (ARAS)

\section{Electronic reference}

Ankita Rathi, "Seeing the Urban from the Agrarian: Emerging Forms of Agrarian Urbanization in India", South Asia Multidisciplinary Academic Journal [Online], 26 | 2021, Online since 07 April 2021, connection on 11 May 2021. URL: http://journals.openedition.org/samaj/7306; DOI: https://doi.org/10.4000/ samaj.7306

This text was automatically generated on 11 May 2021.

\section{$\oplus \Theta \Theta \Theta$}

This work is licensed under a Creative Commons Attribution-NonCommercial-NoDerivatives 4.0 International License. 


\title{
Seeing the Urban from the Agrarian: Emerging Forms of Agrarian Urbanization in India
}

\author{
Ankita Rathi
}

\section{Introduction}

1 There is an extensive body of literature, especially in the context of South Asian urbanization, dedicated to investigating the "urban" beyond the "city" (Brenner and Schmid 2015; Roy 2011, 2015; Gururani 2019; Kennedy and Sood 2016; Denis, Mupkopadhyay, and Zérah 2012; Zérah and Denis 2017; White 2016; Sircar 2016, 2017, 2018). Assessed from the standpoint of diverse conceptual lenses such as "subaltern" or peripheral urbanization, these studies make a critical intervention in the examination of urban processes, in places that have largely remained ignored by the dominant discourses on urbanization (Sircar 2016; Ong and Roy 2015). There is mounting interest in studying the unfolding urban dynamics in the peripheries of large metropolises as well as in small towns in India. The 2011 census of India data revealed the appearance of 2,532 new "census towns" in India. "Census towns" are primarily small urban centers that are deemed "urban" in the national census but continue to be governed by a rural local government body (Panchayats). Works by scholars such as Denis et al. (2012) and Zérah and Denis (2017) have shown that the urban dynamics of these settlements remain autonomous from big cities and metropolitan centers. ${ }^{1}$ They coined the term "subaltern urbanization" to describe the processes of urbanization that take place in small towns, far from metropolitan centers. The urban dynamics of small census towns, as Zerah and Denis (2017) argue, exceed and do not fit into the familiar urban forms and processes in "global" or "world" cities. The dynamics underway in these settlements are rooted in endogenous structures, incorporating knowledge, politics, and situated logics and relationships that differ from the global city. However, such settlements have remained "peripheral," and mostly "unacknowledged" by existing urban theories and state planning (Roy 2011; Simone 2010; Sircar 2016, 2017, 2018). ${ }^{2}$ 
This paper attempts to contribute to this body of work by showing that the urban exceeds the existing territorial boundaries of the city and agrarian relations, histories, politics, and knowledge shape the social geography of the small town.

$221^{\text {st }}$ century India is witnessing a process of urban transformation in places beyond the city, an aspect that is also referred to as a non-metro centric approach to urbanization (White 2016). While it has been assumed that megacities and metropolitan urban centers are engines of growth, it is increasingly recognized that urban peripheries are engaged in dynamics that merit attention in their own right. Kennedy and Sood (2016) argue that, while policymakers position cities as "growth engines," the period post-1990s has experienced rescaling of urban and economic development to urban peripheries in places like Chennai, Hyderabad, and New Delhi. The extensive urbanization occurring in suburban or peri-urban villages, rural areas, and small towns in India over the last three decades presents a clear case for the significance of peripheries in shaping the urban landscape. Considering small towns as forms of "peripheral" and "subaltern" urbanization, this paper argues that the current process of urbanization in India is entangled with the rural, and its historical and contemporary processes of agrarian change. This stands in sharp contrast to the territorial approaches that have predicted the gradual decline of the rural through the capitalist process of urbanization. By precisely focusing on agrarian histories of land and caste, the paper traces the urban transformation of Patran into an agrocommercial town and argues that the urban is a historical category that is continuously made and unmade at different phases of agrarian change. Agrarian changes driven by the existence of a feudal type of land-tenure system, regional peasant movement and state driven land reform and the green revolution have transformed the agrarian regimes of land ownership, property rights and caste relations in Patran and created the condition for the growth of trade and commerce. This paper reveals that such a form of urbanism, is propelled by socio-political changes in the rural and entangled with transformations in the social fortunes and aspirations of the regional caste groups, leads to the coproduction of the rural and the urban (Gururani 2019). The landbased negotiations, investments and work strategies in these places contour the social geography of both rural-urban areas and incorporate labor relationships that have exacerbated caste-based hierarchies, thereby suggesting that the contemporary urban is a "dynamic continuity" of agrarian social relations.

\section{Agrarian urbanism: emerging form of peripheral urbanization in India}

3 There has been little attempt to formally bring in the rural while conceptualizing the urban and urbanization. It is only very recently that Gururani (2019) developed a conceptual framework of "agrarian urbanism" to study the process of social-spatial changes occurring in the urban peripheries. By focusing on the urban peripheries of big cities, the framework makes an explicit intervention in the current work on urbanization in the global south by arguing that the urban is entangled with the agrarian histories of the formation of land, caste-class identities, and global capitalism (Gururani 2019). Existing studies as well as the macro trends of urbanization in India confirm that the classic transition pattern of agriculture-to-industry and rural-tourban has not occurred, thereby indicating that the rural agrarian economy has 
developed complex and dynamic relationships with the urban (Shah and HarrisWhite 2011). Despite the continuous population movement from rural to urban spaces, along with the ongoing changes in the agriculture sector in India (in terms of contribution to the national GDP and economic growth), the agriculture sector employs around $50 \%$ of the total rural main workforce, and the rural continues to be the primary habitation for $70 \%$ of the total population in India (Census of India 2011). This signals that the process of agrarian transformation and urbanization is occurring simultaneously and the two shape each other in complex ways. In his work on agrarian changes in Punjab and Haryana, Jodhka $(1991,2014)$ shows that the processes of green revolution unleashed new aspirations and uncertainties within the dominant landowning castes. As the agrarian economy could no longer fulfill the hopes and aspirations of rural youth, they started to look for options beyond the rural. Along similar lines, I have argued elsewhere that the rural landed class and castes employ differential work and migration strategies and land investments that contour both rural and urban areas to meet the changing conditions in agriculture (Rathi 2020).

4 With its widespread relevance for understanding the nature and process of capitalist development in rural areas, the centrality of the agrarian question for urbanization is starting to be recognized by urban scholars in the global South (Gururani and Dasgupta 2018; Roy 2015). There is a growing body of work that focuses on the renewed importance of the agrarian land question for South Asian urbanization (Gururani 2013, 2019; Gururani and Dasgupta 2018; Anwar 2018; Dubey 2018; Roy 2015; Cowan 2018; Balakrishnan 2018). By focusing on the peripheries of large cities and metropolitan centers, this research captures the crucial ways in which the agrarian histories of land regimes, caste relations and hierarchies are interwoven into the making of peripheral urban villages. By accounting for the complex, heterogeneous and informal arrangements between agrarian and urban communities, state, and private actors, this body of work draws attention to the ways in which agrarian questions of land and peasant differentiation are central to understanding the transformation of rural land to make neo-liberal dreams of rapid urbanization come true.

On the other hand, there are works that also engage in studying the urban dynamics of small towns in India (Zérah and Denis 2017:6; White 2016; Krishnamurthy and Witsoe 2012; Chari 2014). Although primarily focusing on the economic and sociopolitical dynamism of small towns, these efforts showcase the vital ways in which agrarian histories of work, in which land and caste support the specific regional processes of capital accumulation and urbanization. Using subaltern studies as a theoretical standpoint, researchers in these strands of work have embraced the local embeddedness of the process of urban-in-the-making, its agrarian dynamics and its engagement with caste and community politics, among others (Chari 2014; Gidwani 2008; Sircar 2016; Krishnamurthy and Witsoe 2012; White 2016; Basile 2011). This form of urbanization remains intertwined with the rural and its agrarian dynamics. ${ }^{3}$ For instance, in their study of rural migrants in the city of Delhi and Hyderabad, Gidwani and Ramamurthy (2018) observe that even as they gain a foothold in the city, their orientation remains largely agrarian.

6 In engaging with the aforementioned literature on agrarian urbanism, this paper presents a case study from a small agro-commercial town in Punjab. I argue that the making of the "urban" and attendant urbanisms is embedded in the historical and contemporary process of agrarian transformation. In particular, I show how feudal 
forms of the land tenure system and relationship, the peasant movement and stateaugmented agriculture development strategy through land reform and the green revolution are instrumental in shaping the distribution of land among different groups, which in turn influenced Patran's distinct trajectory of urban transformation. Importantly, this form of urbanization not only emerges from the agrarian or is linked to the agrarian but is deeply entangled with the changing agrarian social relations of land and caste. In other words, the rural, a socio-spatial category with its distinct agrarian logics of land, caste, work, and politics is an essential supplement of the unfolding urban in contemporary India (Roy 2015). Thus, the agrarian politics of landcaste and identity and the agrarian questions of: Who owns land? Who works the land? Who gains from land? And what are the diverse arrangements through which everyday practices of labor, profit, speculation, and credit are constitutive of urbanization in the small towns. Furthermore, it is shown that this form of "agrarian urbanism" is not just fuelled by neo-liberal dreams of the global city, but is also constitutive of agrarian aspirations, needs and demands emerging from the changing nature of agriculture in the rural. Agrarian urbanism, as Gururani (2019) argues, involves the coproduction of the "urban" and the "agrarian" as local communities engaged in work and investment beyond the urban into the rural, thereby reinforcing and exacerbating caste-based hierarchies that both mirror and differ from rural agrarian social relations. This form of urbanism confirms that, far from assimilating the rural, agrarian urbanization in its present form instead enables the "rural" and the "urban" to sustain and co-produce each other.

\section{Locating the case study and research methodology}

7 The site for my study is a small agro-commercial town named Patran, located in the Patiala district of Punjab. ${ }^{4}$ I draw on data collected from diverse sources and combine both quantitative and qualitative methods for studying urban transformation. To demonstrate the agrarian-urban entanglement of small towns, I adopt a mixed method of data collection, which provided a distinct advantage of both generalization as well as capturing specific, subjective, and historical experiences of individuals and communities. This comprised both statistical data collected from a household survey as well as in-depth and semi-structured interviews with prominent traders, seasonal and full-time wage labor and old-generation families residing in and around the town. The quantitative data was based on a structured questionnaire sample survey of 500 households in the town. This household survey provided macro data on the socioeconomic demography of the town. More specifically, the household survey collected information on occupational changes, education, caste and religious demography, details of land ownership, tenancy and land rights, the farm and non-farm investments undertaken by the household and the nature of credit practices, both borrowing and lending. The household survey data was analyzed in order to describe the socioeconomic demography of the town. Applying qualitative methods, 20 in-depth interviews were conducted with old generation families residing in Patran and its adjacent villages to trace the changes in land-caste and work dynamics during periods of land-reform and the green revolution. To understand the social, economic, and political dynamics of the agriculture market, 30 semi-structured interviews were conducted with prominent traders and manufacturers in the town. This generated information on the social organization of work and production in the agro-marketing 
sector. In addition, in-depth interviews were also conducted with the seasonal migrant and local labor who worked in the local agriculture market and the construction sector to make sense of their urban experience and the diverse ways in which they responded to the urbanization process.

\section{Situating Patran}

Patran is a small agro-commercial town, classified as a class three urban center. ${ }^{5}$ It currently has a population of 30,000 . It is well-connected to the nearby cities and towns. The National Highway- 1 and State highway-10 eased the mobility of goods and people to and from the town. Located on the south-western edge of Patiala district, Patran is surrounded by Sangrur district in Punjab and proximate to the Jind and Fatehabad districts in the bordering state of Haryana. (See Fig 1) Until the 1980s, it was one of the agriculturally less developed parts of Patiala. It was given the status of a "notified area committee" or $\mathrm{NAC}^{6}$ in the year 1971, when a central marketing agency (Food Corporation of India) and a state regulated agriculture market or a mandi were set up in the town in 1966 and 1968, respectively. By the 1990s, Patran was officially designated as a Nagar Panchayat ${ }^{7}$ because of its vital role as an agro-marketing/ purchase center of paddy and wheat and the presence of agro-related input and output dealers. The town is currently a designated municipal council. ${ }^{8}$

\section{Figure 1: Location of Patran Town}

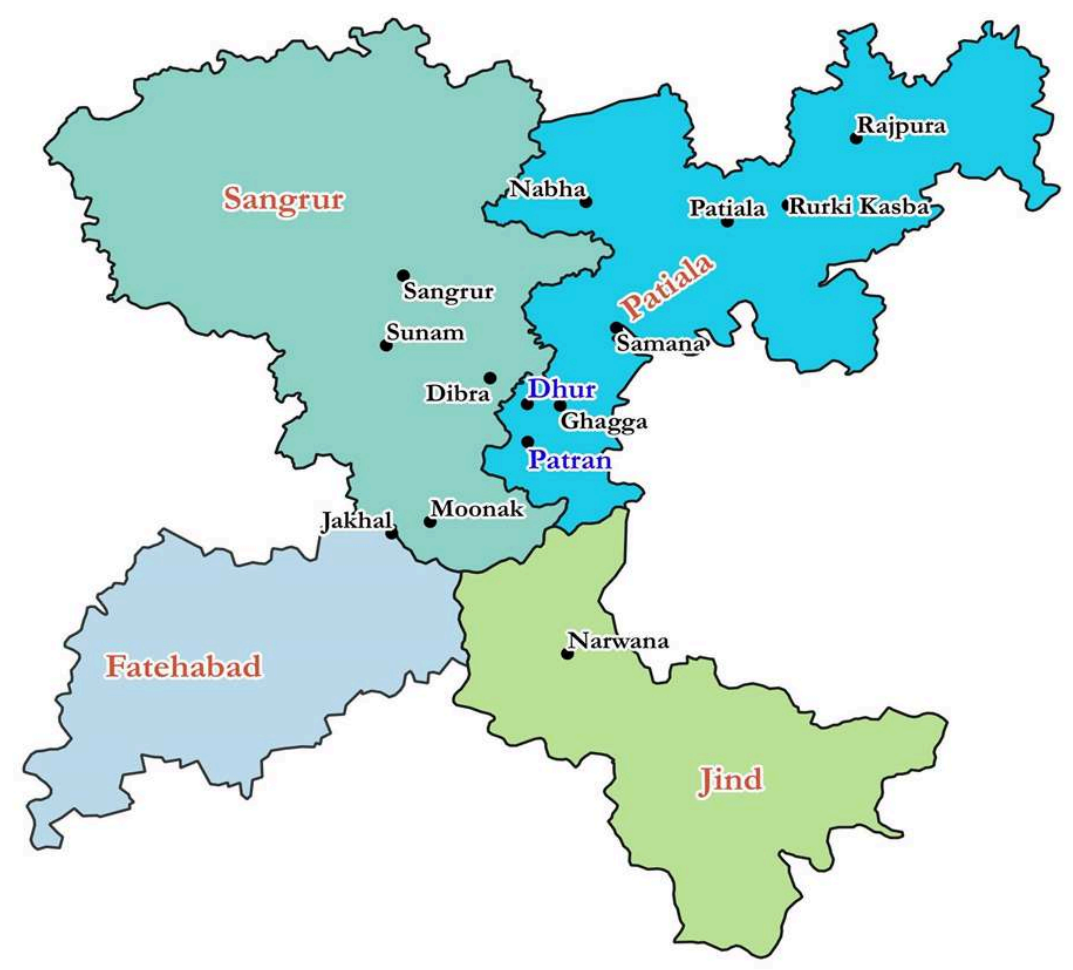

Source: Using Google Earth geo-reference points in ArcGIS.

This map was prepared by the author with the help of Dr. Anand.

Patran's trajectory of urbanization can be traced to the period of agrarian prosperity brought in by the process of green revolution during the 1960s. ${ }^{9}$ At first glance, Patran 
appears to be primarily an agricultural town dealing in paddy, wheat and other agroallied goods and services. Its agrarian character is most prominent during the two harvest seasons when farmers from the nearby villages bring in tractors and reapers full of paddy and wheat to the agriculture market. In fact, some individuals in the community also described the town as kasba, (small town) while referring to the smallness of the town in terms of the persistent link to agriculture and the rural. The aerial view (Google Earth) of the town in Figure 2 below, taken in 2020, shows that the town is surrounded by agricultural fields and villages, and together with the agriculture market, these attributes give the town its agrarian character. However, the anaj mandi (grain market) co-exists with a vibrant consumer market, a bazaar economy that deals in diverse forms of goods and services. This caters to the local people as well as to the agrarian population in the nearby rural areas. While primarily known to be a trading or a business town, more recent agrarian uncertainties in production have created the seeds of a slump and stagnation in the agro-commercial sector.

Figure 2: Aerial location of Patran

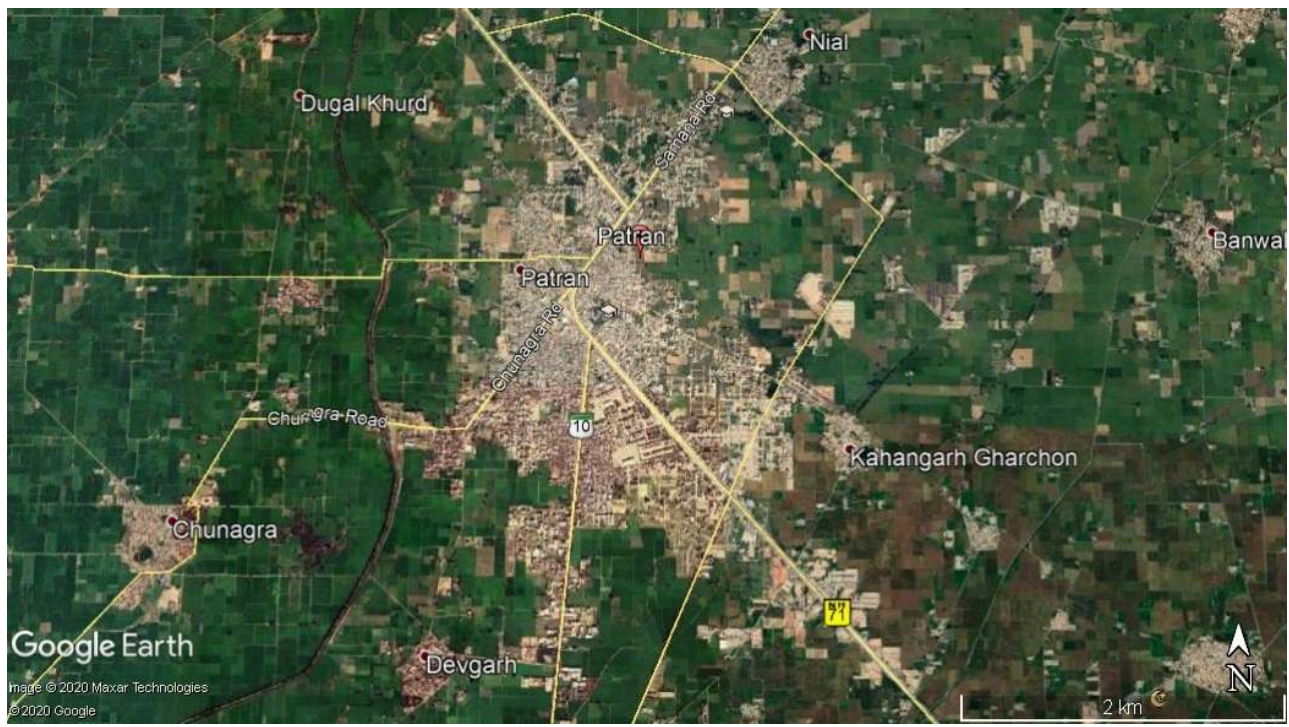

10 Approximately $60 \%$ of the total households in the town identify as Hindus. The Baniyas, especially the big agro-traders and processors are key economic players and wield significant political power in the local administration and politics. Other Hindu groups include Pandit, Khatri and Arora castes. Additionally, there are other communities, those belonging to the Jat Sikhs caste and Scheduled castes. The Jat Sikhs are either involved in public sector jobs or are small agro-traders who have continued to maintain agrarian links with their land in the village. The scheduled castes, primarily belonging to Ramdasia and Mazabhi caste groups, work as casual wage labor in the local agriculture market.

\section{Changing regimes of land, caste and work}

11 The urban transformation of Patran can be traced to its historical agrarian-ecological conditions, mass peasant movements and state driven agrarian reforms of land and market that transformed the agrarian regimes of land and caste and created aspiration for new places of capital accumulation and survival beyond the rural. As I show below, 
diverse agrarian histories encompass heterogeneous experiences of communities and individuals and their struggles, resistances, and negotiation strategies were central to Patran's agrarian transformation and its urbanization.

Patran was part of the princely state of Patiala ${ }^{10}$ and Patiala and East Punjab state Union (PEPSU). The princely rulers and rich landlords, who held positions of power and maintained an aristocratic control over land and the land revenue system vastly impacted the economic condition of the peasantry in this region (Mukherjee 2001). The feudal condition of tenancy and labor relations gave rise to a powerful and the most impactful peasant movement ${ }^{11}$, which started in the 1930 s and persisted till the postindependence period (Mukherjee 2001). In contrast to British Punjab, which experienced intensive agricultural development and peasant protest, the princely state was governed by autocratic princely rulers and the agrarian condition of the peasantry in this part of Punjab remained extremely feudal (Mukherjee 2001). Ecological constraints on cultivation such as arid and sandy soil with erratic and low rainfall coexisting with feudal forms of sharecropping-based tenancy arrangements contributed to peasants' hardships and agrarian underdevelopment in the region.

The PEPSU region comprised two prominent forms of land tenure system, i.e., Bhaichara and Biswedari (Sandhu 2001). The Bhaichara form entails an arrangement where the peasants are primarily owner-cultivators and possess proprietary rights to the land. They paid taxes directly to the state. In the Biswedari form of land tenure, the landlords or Biswedars, locally called Sardars held revenue-collecting and proprietary rights to the land. The tenant cultivators only had cultivating rights to the land and paid rent to the Biswedars (Mukherjee 2001). According to Sandhu (2001) almost $30 \%$ of the total landholdings in the princely state of Patiala were controlled by the Biswedars (Landlords) and Patran was a Biswedari village that had a long history of feudal relationship between the landlords and the tenants (Mukherjee 2001; Sandhu 2001). The landlords belonged mostly to the dominant Jat Sikh caste. Other than the Jat Sikh landlords, there were also a few owner-cultivating peasant proprietors from the Jat Sikh and Pandit castes, and a few small traders and moneylenders belonging to the Baniya caste. However, the landlords controlled the land, revenue rights and tenancy arrangements in the village. During the first Regular Settlement System of Patiala in the first decade of the twentieth century, these landlords, who previously only held revenue-collecting rights, gained proprietary status over the land cultivated by the tenants (Mukherjee 2001). This reduced the status of the Gujars, who held hereditary cultivating rights to the land, to that of occupancy tenants and the Dalits to that of tenants-at will. (Mukherjee 2001; Sandhu 2001). The revenue records classified them as "occupancy tenants" and declared the landlords as "Ala Malik" or super-lord (Walia 1972). This led to frequent tensions between the landlord and the tenants. Interviews conducted with a few of these older Gujar landowners in the town and nearby village revealed that the landlords and tenants had frequent disputes regarding crop sharing and rent. The landlords extracted a larger share of the produce and the tenants faced social harassment for hiding the produce. According to an interview with one such Gujar landowner residing in the town:

The Sardars in Patran and the nearby villages had close ties with Maharaja Bhupinder Singh during the princely rule. This is how they got our land. We had to go to the Sardars' house after the crop was harvested for crop sharing. The landlords often accused us of hiding the total produce. 
harassment of the tenants also existed through other arrangements, like the Kankut system ${ }^{12}$ (Sandhu 2001). Through the early half of the twentieth century, the peasants in the princely states of east Punjab ${ }^{13}$ faced an economic crisis due to declining agriculture prices during the Great Depression and the world wars, indebtedness, lack of industrial, communication and educational development, the extreme burden of land revenue and water tax and control by the urban moneylenders and landlords (Walia 1972). They relied largely on the meager surplus from the landlord's land, and cattle rearing. The emergence of the PEPSU in 1948 and the dissolution of princely rule also did not alter the agrarian condition of the peasantry, especially in the south-western parts of Patiala (PEPSU 1951). Much of the industrial and development activities were concentrated in the erstwhile developed and politically important belts of the district, i.e., the central and eastern parts consisting of the capital city of Patiala and Nabha, both of which had strongly princely connections (PEPSU census 1951).

Feudal forms of agrarian relations, ecological and climatic constraints and uneven geographical and economic development created a fertile ground for the radical peasant movement that started in the 1930s and lasted until the 1950s. Patran and many villages witnessed massive peasant protests organized by the Praja Mandal and the communist party in the state (Sandhu 2001). During in-depth interviews conducted with old-generation families in the town, it was revealed that during the period of peasant agitation, several landlords were forced to give away their land to the Gujars as the movement took a violent turn. ${ }^{14}$ These interviews reveal accounts of Gujars compelled to take on the land of the landlords. According to an interview conducted with an old generation Gujar residing in the nearby village, "One-third of Patran's land belong to the landlords from the nearby village. It is the Lal party (referring to the CPI (M)) headed by Teja Singh and Kirti Kisan Union that had asked the tenants to not pay the rent." My field interviews with these families during 2015-2016 exposed accounts of land negotiations that occurred between the landlords and the tenants. For instance, many landlords negotiated with the tenants and sold parts of their surplus land to the tenants at a fixed rate.

The most notable change that occurred during the period of peasant protest and land reform was of the rise of Hindu caste groups, especially the trading caste, locally referred to as Banias. The Banias were able to purchase large tracts of land from the landlords, many of whom had migrated out to the nearby towns and villages. Some landlords who stayed behind continued to own land even as they lost their previous social and economic status as sole owners of the land. At this juncture, Banias consolidated their position as a non-cultivating class of Hindu traders and landlords and began to directly invest in non-farm work like small-scale trade in machine tools, flour mills, commodities and iron spare parts. The Jat Sikh landlords, who also did not cultivate their own land, invested in small-scale transport and agri-businesses. With the rise of non-cultivating landlords, the caste-based hierarchies were further reinforced as the Dalits did not gain any land and became the new class of agriculture labor, also known as Siri, and provided full-time agricultural services to the landed class in return for a fixed wage. While conducting fieldwork, I learned that only a few Dalit families gained 1 or 2 acres of land, which was then sold to the Hindu traders, who had the economic capacity to cultivate their land. It in this milieu of land-caste changes and the consolidation of land in the hands of a few landowning castes, who were also 
beginning to diversify in non-agricultural ventures, that we can locate the Patran's trajectory of urban transformation. The changes in landownership, proprietary rights, and tenancy rules not only reinforced existing inter-caste hierarchies but it also paved the way for the uneven growth of business and trade during the period of green revolution.

Amid concerns over food security and making India self-sufficient in food grains in the 1960s, the government embarked on a strategy to make agriculture efficient. This idea of development had relied on the assumption that the surplus generated in agriculture could support industrial development and pave the way for economic growth (Macrae 2007). Popularly known as the "Green Revolution" and locally referred to as Hari Kranti, its primary objective was to make agriculture productive through private and public investment in advanced technology, consisting of hybridized seeds and fertilizers for high-yield crops. In the Patiala district of Punjab, private investment in tube-well irrigation and the development of the Bhakra irrigation project in 1963 brought large tracts of uncultivated land under cultivation. As a result, the total irrigated area in the district increased from $38 \%$ in 1962 to almost $65 \%$ by 1972 (District Census Handbook Patiala 1961, 1971) and led to the increase in total cropped area from 518 thousand hectares in 1960-1963 to 560 and 680 thousand hectares by 1970-1973 and 1980-1983 (Statistical Abstract of Punjab 2002). For the same time periods, the total cropped area under paddy increased from 32.3 thousand hectares to 75 and 205.5 thousand hectares respectively (Statistical Abstract of Punjab 2002).

The process of urbanization in the Indian state of Punjab coincided with the above agriculture development strategy of the state (Kundu and Bhalla 2002). The decadal growth rate of urbanization in the state increased from $2.92 \%$ between 1961-1971 to almost $17 \%$ by 1971-1981 (Primary Census Abstract, Punjab 1961, 1971, 1981). The new agriculture policy created demand for agro-based trade and manufacturing, agriculture implements, housing and infrastructure facilities and units, which boosted the growth of many industrial and trading towns in the region (Kundu and Bhatia 2002). Agrarian changes brought in by the process of modernization in agriculture created a dispersed pattern of urbanization and linked the rural agrarian economy to the small and medium towns. For instance, investment in the urban industrial corridor along the Ludhiana, Jalandhar and Amritsar highway and the Grand Trunk (GT) road from Ludhiana to Delhi not only boosted the growth of industries in existing big cities like Ludhiana, Jalandhar, Amritsar and Patiala, but also created manufacturing prospects for many small and medium towns, like the growth of steel re-rolling activities in Gobindgarh town in the Patiala district, Khanna mandi in the Ludhiana district, the grain market town of Samalkha in Haryana and several cycle, steel and engineering industries in the region (Kundu and Bhalla 2002). Although the major industrial activities concentrated in and around former princely and industrial cities like Patiala, Nabha and Rajpura, growth in agriculture production of paddy and wheat in previously less-developed parts of the district supported the growth of agro-trading towns like Patran.

However, the new agriculture policy recalibrated the existing land-caste relationship in the rural. It not only reinforced the existing capital and labor disparities but created internal differentiation within the peasantry by favoring large and middle-sized farmers (Judge 2015; Jodhka 2006; Sinha 2019; Dhanangare 1987; Dutta 2012; Bhalla and Chadha 1982). Land and agriculture constitute essential marker of the Jat Sikh identity 
in the state. Pettigrew (1992), Jodhka (2006) and Kaur (1986) have argued that the Jats take great pride in rurality and agriculture and despised the townspeople for not being physically brave. Jat Sikhs emerged as the prime beneficiary of this agriculture modernization strategy (Jodhka N.d.). Prosperity brought in by the agricultural reforms created a new sense of identity and confidence within the Jat Sikhs. ${ }^{15}$ By investing in technology and leasing land from the small and marginal farmers, they dominated the rural and regional politics. In the neighboring state of Haryana too, it is the Hindu counterpart of the Jat Sikhs and a segment of Ahir Yadavs, a middle caste that benefitted significantly from the green revolution and agriculture policies of the state (Bhalla 1976; Gururani 2019). The Dalits, on the other hand continue to be landless, working as casual agricultural laborers for the dominant castes in the village. In Punjab, only $5 \%$ of the total main workers belonging to the Scheduled Castes are cultivators and approximately $32 \%$ of them work as agricultural labor, signaling the persistence of caste-based hierarchies (Census of India 2011).

20 Agrarian prosperity brought in by green revolution created demand for agro-markets and linked the agrarian economy to the urban. (Mukherjee 1998). The Punjab Agriculture Procurement and Marketing Centre act (APMC) that was passed in the year 1961 required setting up of market yards and purchase centers at various locations. These purchase centers deal with bulk purchases of agriculture commodities from the farmers (Krishnamurthy 2011). The powerful traders in Patran nearby villages utilized their caste-based economic networks and their contacts in the local administrative and political sphere to setup a state regulated purchase center. ${ }^{16}$ The agriculture market created demand for trade, commerce, and business in Patran, thereby creating opportunities for the rural traders and artisans. The demand for skilled-based work in the purchase centers enabled the non-cultivating trading and artisan castes in rural areas to look for options beyond the rural (Judge 2015). An interview with an agrotrader whose family has been residing in Patran for a long period revealed that the Gujars and the Jat Sikhs sold large tracts of their land to the Banias, who then further invested in agro-based trading and processing of paddy and wheat. The commission agents, rice millers and wholesale traders are the key players in the agriculture market, who also wielded significant economic and political power (Sinha 2019). They not only procure and process paddy and wheat on behalf of the state but are the primary source of credit to the rural peasantry. Rural peasantry of all size class relies on the urbanbased agro-traders, locally called arthiya, for production- and consumption-related credit, thereby linking the agrarian economy and the urban.

The prosperity brought in by the process of modernization in agriculture was, however, short-lived and could not be sustained for long (Dutta 2012; Gill 1984; Jodhka N.d., 2006). ${ }^{17}$ The decline in the role of the state in the agriculture sector, especially post-1990s in terms of price, credit, subsidies and procurement, amplified the uncertainties of the rural peasantry (Jodhka 2006; Mukherjee 1998). Inflated material aspirations and consumerism, on one hand, and decline in the productivity of agriculture on the other challenged the previously dominant position of the landowning Jat Sikhs in rural areas (Judge 2015; Singh 1987; Jodhka 2006). As the agrarian economy could no longer satisfy their material aspirations, the rural landed castes started to look beyond the rural. (Jodhka 2014). They aspired to urban lifestyles and infrastructure that the village could not offer. Additionally, the changing sociopolitical situation in the state during the 1980s and 1990s in the form of a rise in the Sikh separatist movement ${ }^{18}$ transformed the social environment of the villages. The 
primary household survey reveals that many Jat Sikh families migrated into the town during the 1980s and 1990s because of communal tensions in the village. The changed social environment in the village due to mass killings, extortion, social isolation, and security concerns led many families to migrate out of the village to the nearby towns. This is reflected in the nature of migration into the town. Table 1 below shows that in the period after the 1980s, the town witnessed a significant inflow of Sikhs. The major sub-group within the Sikhs are the dominant Jat Sikhs as well few others from the Dalit caste of Ramdasia. Jat Sikhs invested their agrarian capital in the agro-trading sector, notably into the transport business, agro-input workshops, and/or as small-scale commission and property agents. Caste, kinship, and access to agrarian networks in the rural areas enabled them to enter the agro-trading business, thereby sustaining the rural-urban links of the town. Their historically dominant position in the state's political and cultural sphere also enabled them to access public sector jobs like those in the state's police department, electricity, and agriculture and in administrative offices such as the agriculture market committee and tehsil office. The big capitalist farmers, who were able to consolidate their position in the rural, channeled their agrarian surplus into low-priced urban land that could be assetized for future residential and property investments.

Although the majority of those who migrated to Patran were small and medium farmers, migrants were also big landowners for whom the rural was no longer a space of power and prosperity. Migration to the town by the dominant Jat Sikhs was a means to enhance their social and economic position, which had begun to change with the changing conditions in agriculture. For the Dalits, belonging to the Ramdasia caste, migration to the town was driven by the declining opportunities for wage work in agriculture, landlessness and the limits to social and economic mobility that motivated them to look to the urban as a place for survival and the means to enhance their social and economic position, one that remained unchanged in the village. It is against this backdrop of changing land-caste and agrarian relationships that the urban transformation of Patran can be located.

Table 1: Distribution of migrant households across religion and caste over time

\begin{tabular}{|l|l|l|l|l|l|l|}
\hline \multicolumn{7}{|l|}{ Religion } \\
\hline $\begin{array}{l}\text { Time } \\
\text { Period }\end{array}$ & Hindu & Sikh & Muslim & $\begin{array}{l}\text { Upper } \\
\text { Castes }\end{array}$ & $\begin{array}{l}\text { Other Backward Classes } \\
(\mathrm{OBC})\end{array}$ & $\begin{array}{l}\text { Scheduled } \\
\text { Castes }\end{array}$ \\
\hline$<1961$ & 83.33 & 16.67 & 0.00 & 50.00 & 33.33 & 16.67 \\
\hline $1961-1971$ & 60.87 & 34.78 & 4.35 & 43.48 & 43.48 & 13.04 \\
\hline $1971-1981$ & 71.24 & 28.10 & 0.65 & 60.78 & 20.92 & 18.30 \\
\hline $1981-1991$ & 63.43 & 35.07 & 1.49 & 63.43 & 18.66 & 17.91 \\
\hline $1991-2001$ & 51.04 & 47.92 & 1.04 & 56.25 & 25.00 & 18.75 \\
\hline $2001-2011$ & 36.23 & 62.32 & 1.45 & 62.32 & 15.94 & 21.74 \\
\hline
\end{tabular}




\begin{tabular}{|l|l|l|l|l|l|l|}
\hline$>2011$ & 15.79 & 84.21 & 0.00 & 63.16 & 10.53 & 26.92 \\
\hline
\end{tabular}

Source: Primary Household Survey, Patran, 2015-2016

\section{Agrarian-urban entanglements of land, labor, credit and work}

The urban in-the-making can be situated at the intersection of differential phases of agrarian transition that occurred in the region. As I show below, agrarian transition and the making of the urban has occurred simultaneously, with each reinforcing the other. This stands in variance with studies on urban peripheries of large cities where the process of agrarian-urban transformation is fuelled by global development dreams (Cowan 2018; Gururani 2019). In two inter-related ways this form of agrarian-urban entanglement has led to the co-production of the rural and the urban. In the subsection below I show this through the nature of land investment and the social relationship of labor that exists in the urban agro-trading sector.

\section{Differential geographies of land investments}

Land investments in Patran can be linked to changing agrarian aspirations as well as the rise in uncertainty in agriculture. Agrarian prosperity brought in by the process of green revolution and the growth of trade and commerce led to the rapid rise in the price of agricultural land in Patran. Even in rural areas adjacent to Patran, the price of such land increased rapidly. The market price of land in Patran increased from 500 to 5000 INR per acre by the early 1960s. ${ }^{19}$ Investment in land commenced even before its formal designation as a regulated state assured purchase center. The booming land market motivated both agrarian and the non-agrarian castes in the town to engage in multiple and differential forms of land purchase, sales, and rental arrangements. The markets and the growth of trade and commerce increased the value of the low-quality arid and barren land in Patran and its adjoining villages.

With the coming of the agriculture market and the opportunity associated with growth in trade and commerce, the barren and uncultivated surplus land, which was thus far considered to be low-quality became attractive for urban development and investment. As also observed by Gururani (2019) in the urban villages near Gurgaon, the value of land in Patran was no longer just determined by irrigation and technology but by the market and its ability to attract trade and commerce. The rise in price of land became a lucrative means to accumulate capital. At this juncture, the Gujars, who had attained land during the land reforms, found it profitable to sell their small landholdings to the Hindu traders, who wanted to kick-start trade and commerce. Mostly, the Gujars landowners who sold their land in Patran to the Hindu traders settled in the nearby villages and were able to capitalize on soaring land values as well as enter the urban non-farm sector. Additionally, for the Gujars, whose land rights historically remained contested and who faced the social harassment of tenancy, the opportunity to increase their landholding in the urbanizing area was an important means for achieving mobility in their economic and social status. 
This strategy of selling and reinvesting in agricultural land has also enabled the Gujars, as in the case of Gurgaon, to get a foothold in the urban and enter its non-farm sector. For instance, one of the Gujar landowners, who provided land for the Food Corporation of India (FCI) storage center in the town, was able to purchase better quality land in the nearby village and secure a government job in the local FCI office. The more entrepreneurial among the Gujars have been able to buy more land, build bigger houses, buy productive assets like tractors, and enjoy conspicuous consumption. Some of them also now hire agricultural labor to cultivate their land. Similarly, Gujars with small landholdings combine agrarian work with non-farm work in the town to compensate for the precarious and seasonal nature of the agricultural work. An interview conducted with a family that resides in a village adjacent to the town revealed that in many Gujar families, male members work as casual wage labor in the rice mills and the agriculture market.

The Jat Sikhs have in similar ways engaged in differential forms of land sale and purchase that span across both rural-urban areas. During the period of agrarian prosperity brought in by the green revolution, Jat Sikhs took great pride in rurality and invested heavily in agricultural land, but with the soaring land prices, they too sold their barren and uncultivated land in Patran to purchase less priced and better-quality land in the nearby villages. It enabled them to consolidate their social status as the dominant landowning castes in the region.

Agrarian uncertainties, especially in the period after the 1980s have transformed the existing social position of the Jat Sikhs. The risks associated with dependence primarily on farming as well as aspirations to urban services and consumption have led to diversification into the urban non-farm sector. The entry of the agrarian castes from rural areas into the urban has not, however, cut off agrarian ties associated with land, agriculture and the village. Most of the farmers who live in towns like Patran continue to own agricultural land in the village. Primary household survey data conducted in 2015-2016 suggests that $79 \%$ of the total Jat Sikh households in the town own agricultural land in the nearby villages. For instance, the Jat Sikhs landowners I spoke with, who migrated from the agriculturally poor and unirrigated districts of Haryana (Karnal, Hissar and Jind) and western Punjab (Bathinda and Mansa) spoke of agrarian distress associated with dry and arid land and uncertainty associated with cotton cultivation and the small size of landholdings. By selling their property and agricultural land in their native villages, they were able to purchase good quality fertile land in villages closer to the town. As the Jat Sikhs enter the urban non-farm sector, their agriculture land in the nearby village is mostly cultivated with the help of seasonal or full-time agricultural labor or Siri. They only supervise and monitor cultivation, as agriculture work is primarily done using agricultural labor by employing modern technology. In this way, agrarian changes have transformed the social identity associated with land. In their work on transnational migration in Punjab, Taylor, Singh, and Booth (2007) argue that "land ownership is still central to izzat (honor) and caste dominance within the contemporary transnational Punjabi community. However, high izzat no longer primarily derives from the agricultural cultivation of land but is asserted by using land for migration-derived consumerism" (p. 332).

The influx of agrarian and trading capital heightened the demand for material goods, as well as conspicuous consumption. In Patran, this is signaled by the nature of borrowing by the households. The primary household survey shows that, other than 
business-related investment loans, credit was taken for housing construction as well to meet immediate household expenditures and consumption needs. This has implications for the transformation of land and the social geography of the town. The agrarian and trading surplus was utilized to buy plots for real estate, property, and rental purposes. The elite and economically powerful Hindu agro-traders invested their trading capital in commercial plots, palatial homes, property, villas, and vacant plots of land for future sales. Figure 3 shows the residence of a big agro-trader and property builder in the town. In contrast to other localities that are referred to as Basti, this settlement is locally called "model town," and is popular for being the grand upper-class colony in the town. Similarly, Figure 4 shows a settlement where Dalit and OBC casual wage workers reside. The land belongs to a powerful and rich agro-trader and is rented out to low-income families. Most property dealers, builders and contractors in the town belong to the Hindu Bania caste. They have been able to leverage and channel their agro-trading capital in the urban construction sector, thereby dominating all forms of major agro-based and non-agro based sectors in the town. Additionally, some of the major property agents/developers assist real estate contracts on behalf of state urban planning institutions, such as PUDA. For instance, PUDA or the Punjab urban planning and development authority, ${ }^{20}$ approved a residential and commercial complex, Sun City, in the town in 2012. The real-estate agent responsible for this project also belongs to the Bania caste.

Figure 3: A house in Model Town in Patran

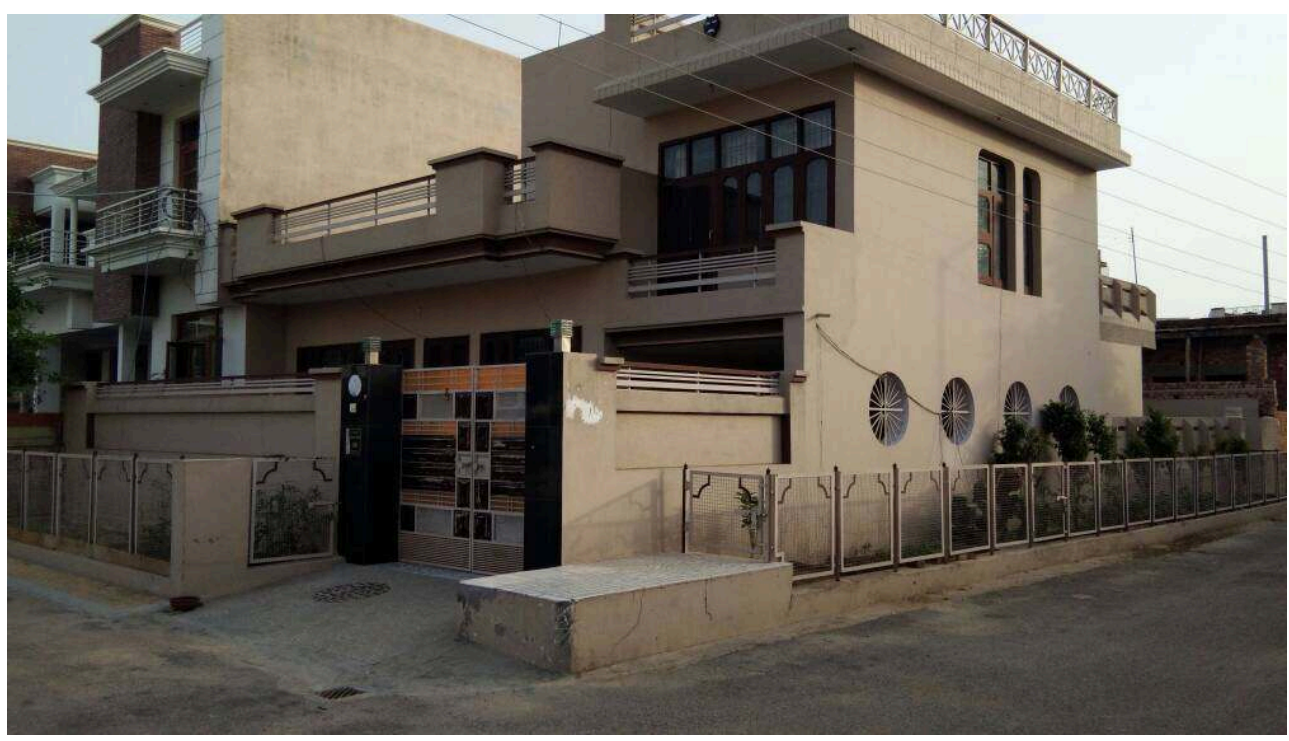

Agrarian uncertainties in production also impacted the business and growth prospects of the agro-traders. The big agro-traders in the town have continued to reinvest part of their trading capital in agriculture. This was an important means to maintain a steady flow of agricultural produce at a time when production witnessed a gradual slowdown. Limited opportunities to grow beyond agriculture and agro-trading further reinforced urban-agrarian linkages. Semi-structured interview surveys of prominent traders and manufacturers in the town indicate that $80 \%$ of the interviewed agro-traders own agriculture land. An interview with a big rice mill owner, who produces export and high-quality parboiled rice, revealed that he owns 50 acres of agricultural land in a village approximately $10 \mathrm{~km}$ from Patran. The land is cultivated using full-time 
agricultural labor from among the Dalits. Typically, most of the big agro-firm proprietors own agricultural land in the ancestral village they migrated from. They have also purchased more agriculture land in the nearby villages for business and investment purposes. For instance, as agro-trading and commercial units are located within the urban, most agro-processing units have dispersed to the nearby villages.

These land investments have reinforced and exacerbated the caste-based hierarchies that existed in the rural and are expressed in contemporary labor and hiring practices. The agro-commercial investments undertaken by the big agro-commercial paddy processors and traders in the town have relied on new models of labor hiring arrangements and used agricultural land to reach corporate and commercial goals like the export of parboiled rice. The plants, known as SELA rice plants, relied on differential labor hiring arrangements to accumulate capital that has reinstated caste hierarchies and agrarian dependencies. ${ }^{21}$

Table 2: Distribution of households across caste and occupation (\% of $\mathrm{HH})$

\begin{tabular}{|l|l|l|l|l|}
\hline Caste/Sector & Trade & Manufacturing & Regular Wage Work & Casual Wage Work \\
\hline Upper Castes & 78.13 & 62.00 & 72.00 & 27.00 \\
\hline Other Backward Classes & 22.00 & 38.00 & 12.00 & 17.10 \\
\hline Scheduled Castes & 0.00 & 6.25 & 16.00 & 57.00 \\
\hline
\end{tabular}

Source: Primary Household Survey, Patran, 2015-2016

The big agro-processors hire both full-time and casual contractual wage labor to produce par-boiled rice. ${ }^{22}$ The causal wage labor is mostly hired with the help of contractors, locally called thekedar. They are male seasonal migrant laborers from the states of Bihar, Haryana, and Uttar Pradesh. Most of them belong to the Dalit caste, who directly assist in the production of par-boiled rice alongside other tasks like loading and unloading of paddy. ${ }^{23}$ To survive and maximize their wage earning resulting from the migration, they often engage in seasonal agriculture work along with urban wage work during the paddy and wheat sowing and harvesting season. The nature of a migrant being seasonal in nature, the migrants stay close to agricultural fields during the agricultural work season. Sometimes they live in thatched black sheet huts near the mandi or inside the mills and processing units in small quarters provided by the millers. In the construction sector as well, labor is mostly hired locally with the help of local contractors. Casualization of wage work and the recent slump in property/construction work in the town has forced them to undertake agricultural wage work in the lands of the upper castes in the nearby villages and has kept the casual seasonal and local wage labor tied to agricultural wage work. Additionally, it has reinforced interlocking credit contractual agreements between the upper castes and the wage labor. ${ }^{24}$ The urbanity of the town, in this sense, is what Sircar (2016) referred to as the "dynamic continuity" of the social relations of the agrarian social order. 


\section{Conclusion}

Through the conceptual lens of agrarian urbanism, I show that the contemporary processes of urbanization in places go beyond the "city" and are deeply embedded in the rural and its changing agrarian dynamics. By tracing the agrarian histories and relationships of land and caste in Patran, a small town in Punjab, the paper highlights that the urban is meshed with the different phases of agrarian change. The historically dominant feudal land tenure system, and the regional peasant movements to end landlordism transformed the existing property rights, patterns of landownership and caste relations, thereby producing uneven geography of trade and commerce in Patran. It is observed that this form of agrarian urbanism is responding to changing agrarian aspirations and needs and not just fuelled by neo-liberal and global dreams. The agrarian prosperity brought in by the process of green revolution created opportunities for the rural caste groups to get a foothold in the urban and expand trade and commerce. The rising precarity and uncertainty in agriculture, have, however, not withered agrarian ties to land, agriculture and the rural as urban caste-groups continue to own land and invest in agriculture even as they gain entry into the urban non-farm sector. Thus, the agriculture sector, despite experiencing uncertainty provides a useful safety-net for urban groups. This, I argue is a crucial intervention in the existing work on urbanization that has traditionally ignored the dynamics of the rural in our contemporary understanding of urban beyond the "global" and "world" city.

Furthermore, this form of urbanism that is rooted in the agrarian does not assimilate the rural but leads to its coproduction. The land investments and work activities undertaken by the urban groups in Patran span across both rural and urban areas. The land and economic investments in the urban incorporate new models of labor hiring arrangements and utilize agriculture land for corporate actors, each of which have persistant caste-based hierarchies. The economic relations maintained through a differential form of labor hiring arrangements have reinstated caste-based hierarchies that existed in the rural, thereby showcasing a "dynamic continuity" of rural social relations, an issue that has bothered scholars from both urban and agrarian studies. Thus, the form the urban takes both mirrors as well as differs from rural agrarian relations of land, caste and labor.

\section{BIBLIOGRAPHY}

\section{Academic References}

Alam, Javeed. 1986. “Political Implications of Economic Contradictions in Punjab." Social Scientist 14(10):3-26.

Anwar, Nausheen. 2018. "Receding Rurality, Booming Periphery." Economic \& Political Weekly 53(12):46-54. 
Balakrishnan, Sai. 2013. "Highway Urbanization and Land Conflicts: The Challenges to Decentralization in India." Pacific Affairs 86(4):785-811.

Balakrishnan, Sai. 2018. "Seeing Mumbai through Its Hinterland: Entangled Agrarian-Urban Land Markets in Regional Mumbai.” Economic \& Political Weekly L111(12):55-60.

Bardhan, Pranab, and Ashok Rudra. 1978. "Interlinkage of Land, Labor and Credit Relations: An Analysis of Village Survey Data in East India." Economic \& Political Weekly 13(6-7):367-84.

Basile, Elisabetta. 2011. "From the Green Revolution to Industrial Dispersal: Informality and Flexibility in an Industrial District for Silk in Rural South India." European Journal of Development Research 23(4):598-614.

Bhaduri, Amit. 1986. "Forced Commerce and Agrarian Growth.” World Development 14(2):267-72.

Bhalla, G.S., and G.K. Chadha. 1982. "Green Revolution and the Small Peasant: A Study of Income Distribution in Punjab Agriculture: I." Economic \& Political Weekly 17(20):826-33.

Kundu, Amitabh, and Sutinder Bhatia. 2002. "Industrial Growth in Small and Medium Towns and Their Vertical Integration: The Case of Gobindgarh, Punjab, India." Management of Social Transformation. Discussion Paper 57. United Nations Educational Scientific and Cultural Organisation, Paris.

Breman, Jan. 1996. Footloose Labour: Working in India's Informal Economy. Cambridge University Press.

Brenner Neil, and Christian Schmid. 2015. “Towards a New Epistemology of the Urban?" City 19(2/3):151-82.

Chari, Sharad. 2004. "Provincializing Capital: The Work of an Agrarian Past in South Indian Industry." Comparative Studies in Society and History 46(4):760-85.

Cowan, Thomas. 2018. "The Urban Village, Agrarian Transformation, and Rentier Capitalism in Gurgaon, India.” A Radical Journal of Geography 50(5):1244-66.

De Haan, Arjan. 2002. "Migration and Livelihoods in Historical Perspective: A Case Study of Bihar, India." The Journal of Development Studies 38(5):115-42.

Denis, Éric., Partha Mupkopadhyay, and Marie-Hélène Zérah. 2012. "Subaltern Urbanization in India." Economic \& Political Weekly 47(30):52-62.

Dhanangare, D.N. 1987. “Green Revolution and Social Inequalities in Rural India.” Economic \& Political Weekly 22(19-21): AN137-AN144.

Dubey, Shruti. 2018. "Urban Transformations in Khora Village, NCR: A View from the 'Periphery." Economic \& Political Weekly 53(12):77-83.

Dutta, Swarup. 2011. "Green Revolution Revisited: The Contemporary Agrarian Situation in Punjab, India." Social Change 42(2):229-47.

Gidwani, Vinay. 2008. Capital, Interrupted: Agrarian Development and the Politics of Work in India. Minneapolis; London: University of Minnesota Press.

Gidwani, Vinay and Priti Ramamurthy. 2018. "Agrarian Questions of Labor in Urban India: Middle Migrants, Translocal Householding and the Intersectional Politics of Social Reproduction." The Journal of Peasant Studies 45(5-6):994-1017

Gill, Sucha. S., and K.C Singhal. 1984. "The Punjab Problem: Its Historical Roots.” Economic \& Political Weekly 19(14):603-08. 
Gururani, Shubhra. 2019. "Cities in a World of Villages: Agrarian Urbanism and the Making of India's Urbanizing Frontiers.” Urban Geography 41(7):971-89.

Gururani, Shubhra. 2013. “Flexible Planning: The Making of India's 'Millennium City,' Gurgaon.” Pp. 119-43 in Ecologies of Urbanism in India, edited by A. Rademacher, and K. Sivaramakrishnan. Hong Kong University Press.

Gururani, Shubhra, and Rajarshi Dasgupta. 2018. "Frontier Urbanism: Urbanisation beyond Cities in South Asia." Economic \& Political Weekly 52(12):41-45.

Harriss-White, Barbara. 2016. Middle India and Urban-Rural Development: Four Decades of Change. Springer. India.

Heeger, Gerald. 1972. "The Growth of the Congress Movement in Punjab, 1920-1940.” The Journal of Asian Studies 32(1):39-51.

Jodhka, Surinder Singh. N.d. "Caste and Power in the Lands of Agriculture: Revisiting Rural North-West India.” Unpublished manuscript.

Jodhka, Surinder. 1994. "Agrarian Changes and Attached Labour: Emerging Patterns in Haryana Agriculture.” Economic \& Political Weekly 29(39):A102-A106.

Jodhka, Surinder. 2012. “Agrarian Changes in the Times of (Neo-liberal) 'Crises': Revisiting Attached Labour in Haryana." Economic \& Political Weekly 47:26-27.

Kennedy, Loraine, and Ashima Sood. 2016. "Greenfield Development as Tabula Rasa: Rescaling, Speculation and Governance on India's Urban Frontier.” Economic \& Political Weekly L1(17):41-49 Krishnamurthy, Mekhala, and Kapur Devesh. 2016. "Understanding Mandis: Market Towns and the Dynamics of India's Rural and Urban Transformations." eSocialSciences Working Papers. id: 8402 .

Krishnamurthy, Mekhala. 2011. "Harda Mandi: Experiencing Change in an Agricultural Market in Central India (1980-2010).” PhD dissertation, Department of Anthropology, University College London, London.

Leaf, Murray. 1983. "The Green Revolution and Cultural Change in a Punjab Village, 1965-1978." Economic Development and Cultural Change 31(2):227-70.

Macrae, John. 1971. "The Relationship between Agricultural and Industrial Growth, with Special Reference to the Development of the Punjab Economy from 1950 to 1965." The Journal of Development Studies 7(4):397-422.

Merrifield, Andy. 2014. The New Urban Question. London: Pluto Press.

Mooney, Nicola. 2011. Rural Nostalgias and Transnational Dreams: Identity and Modernity among Jat Sikhs. University of Toronto Press.

Mukherjee, Mridula. 2001. Peasants in India's Non-violent Revolution: Practice and Theory. New Delhi: Sage Publications.

Mukherji, Partha Nath. 1998. “The Farmers' Movement in Punjab: Politics of Pressure Groups and Pressure of Party Politics." Economic \& Political Weekly 33(18):1043-48.

Oberoi, Harjot. 1997. "Sikh Fundamentalists." Pp. 318-32 in Politics in India, edited by S. Kaviraj. Delhi: Oxford University Press.

Rathi, Ankita. 2020. "Is Agrarian Resilience Limited to Agriculture? Investigating the 'Farm' and 'Non-farm' Processes of Agriculture Resilience in the Rural." Journal of Rural Studies. Retrieved April 72021 (https://doi.org/10.1016/j.jrurstud.2019.12.015). 
Roy, Ananya. 2015. “What is Urban about Critical Urban Theory?" Urban Geography 37(6):810-23. Sandhu, Narinder. 2001. "Feudalism, Peasant Movement and Process of Land Reform in Patiala." Pp.118-36 in Land Reform in India: Intervention for Agrarian Capitalist Transformation in Punjab and Haryana, edited by S.S. Gill. New Delhi: Sage Publications.

Shah, Alpa, and Barbara Harris-White. 2011. "Resurrecting Scholarship on Agrarian Transformations.” Economic \& Political Weekly 46(39):13-18.

Sharma, Alakh. 2005. “Agrarian Relations and Socio-Economic Changes in Bihar.” Economic \& Political Weekly 40(10):960-72.

Shiva, Vandana. 1991. The Violence of Green Revolution. London: Zed Books.

Sidhu, H.S. 2002. "Crisis in Agrarian Economy in Punjab: Some Urgent Steps." Economic \& Political Weekly 37(30):3132-38.

Simone, Abdou Maliq. 2010. City Life from Dakar to Jakarta. New York: Routledge.

Sinha, Shreya. 2019. "The Politics of Markets: Farmer-trader Relations under Neoliberalism in Punjab, India." Journal of Agrarian Change 20:255-69.

Sircar, Srilata. 2016. "Between the Highway and the Red Dirt Track: Subaltern Urbanization and Census Towns in India." PhD dissertation, Department of Human Geography, Lund University, Sweden.

Sircar, Srilata. 2017. "Placing the Urban in its Rural Context: A Mixed Methods Case Study of a ‘Census Town' in India.” Urbanisation 2(2):1-18.

Sircar, Srilata. 2018. "'You can call it a Mufassil Town, but nothing less': Worlding the New Census Towns of India." Geoforum 91:216-26.

Taylor, Steve, Manjit Singh, and Deborah Booth. 2007. "Migration, Development and Inequality: Eastern Punjabi Transnationalism." Global Networks 7(3):328-47.

Walia, Ramesh. 1972. Praja Mandal Movement in East Punjab States. Patiala: Dept. of Punjab Historical Studies, Punjabi University.

Wilson, Kalpana. 1999. "Patterns of Accumulation and Struggles of Rural Labour: Some Aspects of Agrarian Change in Central Bihar." The Journal of Peasant Studies 26(2-3):316-54.

Zérah, Marie Hélène, Denis, Éric. 2017. "Reclaiming Small Towns.” Pp. 1-35 in Subaltern Urbanisation in India: An Introduction to the Dynamics of Ordinary Towns, edited by É. Denis, and M.H. Zérah. Springer, India.

\section{Official documents}

Census of India. 1991. Village Directory. Patiala, Punjab

Census of India. 2001. Village Directory. Patiala, Punjab.

Census of India. 2011. Village Directory. Patiala, Punjab.

Census of India. 1951. District Census Handbook. District Patiala. The authority of the PEPSU government. Simla. Vol. 1.

Census of India. 1961. District Census Handbook. Patiala, Punjab.

Census of India. 1971. Primary Census Abstract. Patiala, Punjab.

Census of India. 1981. Primary Census Abstract. Patiala, Punjab.

Census of India. 1991. Primary Census Abstract. Patiala, Punjab. 
Census of India. 2001. Primary Census Abstract. Patiala, Punjab.

Census of India. 2011. Primary Census Abstract, Patiala, Punjab.

Economic and Statistical Organisation. 1990. "Statistical Abstract of Punjab.” Punjab.

Economic and Statistical Organisation. 1995. "Statistical Abstract of Punjab.” Punjab.

Economic and Statistical Organisation. 2004. "Statistical Abstract of Punjab." Punjab.

Economic and Statistical Organisation. 2010. "Statistical Abstract of Punjab.” Punjab.

\section{NOTES}

1. Through her ethnographic investigation of census towns in West Bengal, Sircar (2016) argues that the urban dynamics of these settlements are deeply embedded in the rural and its agrarian dynamics.

2. In fact, Simone (2010:14) and Roy (2015) have insisted on the need to break away from a metrocentric understanding of urbanization and study the urbanism of cities that are at the periphery of urban analysis and have thereby remained largely ignored.

3. Studies, especially those based in India show that the process of rural to urban migration is a non-linear process as communities continue to locate work, credit, land, and labor in both rural and urban areas through new forms of seasonal migration into the city (Gidwani and Ramamurthy 2018; Shah and White 2011).

4. The fieldwork for this paper was conducted for nine months starting in August 2015 as part of my PhD thesis at the National Institute of Advanced Studies, Bangalore.

5. According to the Census of India, a class three urban center is a settlement whose population is between 20,000-49,999.

6. A notified area committee is a partially or fully nominated local body for which notification has been issued.

7. Nagar Panchayats are administrative local bodies for transitional areas experiencing rural to urban transition (Census of India). In Punjab, the Nagar Panchayat are usually settlements with a population of 5,000 and above and an income of less than 15 lakh (Punjab Municipal act 1911).

8. A municipal council is a local administrative body for smaller urban areas, or a Municipality constituted under sub- section (2) of section 4 of the Punjab municipal act, 1911 for a smaller urban area.

9. The population growth rate during the 1961-1971 period was $29.76 \%$. It declined thereafter from 9.57 \% for the 1971-1981 period to almost 2.61\% for 2001-2011 (Census of India 1961, 1971, 2001, 2011).

10. Patiala was the capital city of Patiala and East Punjab state Union (PEPSU). PEPSU was merged with the rest of Punjab in 1956.

11. The origin of this movement dates back to the first regular settlement of Patiala, when the Biswedars (local landlords), who only had revenue-collecting rights claimed, due to their growing influence in the administration, proprietor status over the land belonging to the cultivating proprietors (Mukherjee 2001).

12. In this system, standing crops were assessed by the committee consisting of a state official and the landlord. It fixed the share of the produce to be paid to the landlord or batai (Mukherjee 2004; Sandhu 2001).

13. East Punjab implies that part of British Punjab which came to India after partition in 1947. East Punjab states covered by Walia (1972) in his study consisted of Patiala, Nabha, Kapurthala, Jind, Faridkot, Malerkotla and Kalsia. 
14. According to Mukherjee (2001), the period witnessed violent clashes between the tenants and the landlords. The tenants refused to pay the batai or share of their crops and attempted to forcibly encroach upon the landlords' land.

15. It is only after the green revolution that the Sikh image came to be identified with the Jat Sikhs (Pettigrew 1995).

16. Interviews revealed that Jat Sikhs landlords and landowners strongly resisted this, as they feared the rise of Hindus in trade and commerce at the cost of agriculture.

17. Referring to it as "Punjab problem" and "agrarian crisis," studies have observed the impact of rising costs of inputs, sub-division of landholdings, slow growth of the market price of major crops, declining state-support to the agriculture sector and falling returns from agriculture on the economic and socio-political transformation which occurred in the rural (Dutta 2012; Leaf 1985; Jodhka 2006; Sidhu 2002; Singh 2017; Alam 1986).

18. The Sikh separatist movement, widely known as the Khalistan movement comprised of Sikh mobilization seeking a separate nation of Khalistan. Many studies on the Khalistan movement in Punjab trace the emergence of the movement to the rising economic inequality and political economy of the green revolution in Punjab (Oberoi 1997; Shiva 1991).

19. Interview with a commission agent, Patran, 2016

20. It is an apex institution established in 1995 for balanced urban growth in the state of Punjab. It was established for creating planned residential, commercial, and industrial spaces.

21. Sircar (2017) argues that "the caste relations, which are also labor relations, have been modified to fit the emerging forms of economic organization but not transformed in terms of the flows of power and authority" (p. 16).

22. The full-time laborers are upper-caste males belonging to the Pandit and Baniya caste. They either reside in the town or commute from the nearby village and primarily undertake skilled jobs like banking, accounting, communication and I.T. in these firms.

23. Landlessness, unemployment, and limited opportunity for social mobility in their home village led them to migrate and search for employment outside their state (Sharma 2005; Haan 2002; Wilson 1999).

24. They often rely on advance credit borrowings from the agro-traders, processors, and landowners to manage their cost of living in the off-season period. The advance payment is repaid through intense wage work during the peak season.

\section{ABSTRACTS}

Conventionally, the city has been the dominant conceptual basis for understanding urban processes. The rural, on the other hand, is assumed to be external to the city, which is supposedly subsumed by the global forces of capitalist urbanization. Such a conceptualization underestimates the complex ways in which the rural, with its distinct agrarian dynamics of land, labor and capital, is significant in understanding the processes of urbanization that are anchored in geographies beyond the city. Using the framework of "agrarian urbanism" (Gururani 2019), this paper focuses on a small town, Patran, located in the Patiala district of Punjab and argues that contemporary processes of urbanization are deeply entrenched in the rural and its agrarian dynamics of land and caste. By focusing on agrarian changes that were driven by colonial policies of land rights and ownership, and state-led agrarian development strategies in post-independent India, this paper argues that instead of assimilating the rural, urbanization in predominantly 
agricultural contexts both mirrors and differs from the old forms of agrarian relations and leads to the coproduction of the rural, albeit in new ways.

INDEX

Keywords: agrarian, urban, agriculture market, land, caste, agrarian change, small towns

\section{AUTHOR}

\section{ANKITA RATHI}

Research Fellow, Institute of Rural Management Anand, Gujarat, India. 